\title{
ASSESSMENT OF HEALTH STATUS IN FIBER GLASS WORKERS: ROLE OF CHROMIUM WITH BIOLOGICAL ANTIOXIDANTS.
}

1. MBBS, M.Phil

Associate Porfessor Biochemistry

FMH College of Medicine and

Dentistry Lahore.

2. MBBS, M.Phil

Associate Professor Biochemistry

FMH College of Medicine and

Dentistry Lahore.

3. MBBS, M.Phil

Assistant Professor Biochemistry Shifa Medical and Dental Collage Islamabad.

4. MBBS, M.Phil

Professor Biochemistry

Rai Medical College, Sargodha.

5. MBBS, M.Phil, Ph.D

Associate Professor

Sulaiman Al-Rajhi Colleges, Saudi Arabia.

6. M.Phil, Ph.D

Professor Biochemistry

Institute of Molecular Biology and

Biotechnology, University of Lahore.

Correspondence Address:

Dr. Uzma Jabbar

House No.3, Block B 2.

Nasheman-e-lqbal Housing Society

Phase-II, Lahore.

uzmaimran5874@gmail.com

Article received on:

13/09/2019

Accepted for publication:

12/12/2019

\section{INTRODUCTION}

The health hazards of manmade fibers are known, as the structure of fiber glass is alike asbestos fibers and may be the reason of respiratory problems like asthma, pneumonia, and lung cancer etc. ${ }^{1,2}$ Chromium compounds are used in many industries including preservatives of wood, alloys, in alkylation reactions, halogenation, for hydrocarbon's cracking etc. ${ }^{3}$ Additionally in some industries there is an emission of chromium due to certain processes like fiber glass where the chromium production is nearly $100 \%$. Stable forms of chromium are $\mathrm{Cr} \mathrm{VI}$ and $\mathrm{Cr}$ III which are proved to be carcinogens by inhalation as minimum as $01 \mu \mathrm{g} / \mathrm{m} 3$ in a day. ${ }^{4,5}$

Factors related with toxicity of chromium compounds are oxidative ability of chromium, and its solubility. ${ }^{6}$ It is proposed that carcinogenicity persuaded by Chromium VI may be due to reduction of bio reactive products results in the production of reactive oxygen species (ROS). These ROS may cause DNA damage, forming the breaks of DNA strand and oxidative DNA lesions. Cell membrane is the most susceptible to free radicals and may experience lipid peroxidation, and generate mutagenic Malondialdehye and other DNA adducts. ${ }^{7}$

In mitochondria and microsomes the chromium $\mathrm{VI}$ reduced to $\mathrm{Cr}$ III by ascorbic acid, catalase (CAT) and glutathione peroxidase (GPx) etc and produce free forms of oxygen and molecular forms of oxygen radicals. This molecular oxygen reduces to produces superoxide radicals, which are further reduced to hydrogen peroxide by superoxide dismutase (SOD). ${ }^{8,9}$

Antioxidants enzymes like catalase, glutathione are commonly used as oxidative stress 
markers. ${ }^{10}$ These biomarkers, are important in the maintenance of homeostasis for functions of cell as well as activate the body immune system. These antioxidants also stabilizes the oxidative stress and abolish the toxic effects of heavy metals via the action of synergism. ${ }^{11,12}$

Oxidative stress occurs when excessive formation of ROS overwhelms the antioxidant defence system, as is maintained by antioxidants such as ascorbic acid, alpha-tocopherol, glutathione, carotenoids, flavonoids and antioxidant enzymes which include SOD, catalase and glutathione peroxidase. ${ }^{7}$ SOD scavenges the toxic superoxide ions and converts into hydrogen peroxide, which is maintained by the glutathione system while GPx prevent the peroxidation of cell membrane. ${ }^{13}$

This Study was designed to find out the role of chromium with biological antioxidant and how these can relate with the health status of fiber glass workers.

\section{MATERIAL \& METHODS}

Study was included the fifty workers of fiber glass industry with 4-5 years' experience or time of exposure. A questionnaire based on age, BMI, duration of their work in fiber glass along with their dietary habits etc was filled. Letter of consent was taken from each participant. The study was carried out according to the rule of Helsinki Declaration on human and was endorsed by the ethical committee of the University of Lahore Pakistan.

Workers who are smokers or have a treatment with corticosteroid or non steroidal drugs were excluded from the study. Twenty controls with no history of working in any industry and have no disease was taken as controls. Their blood samples were drawn to estimate the level of chromium and of biological antioxidant serum catalase, superoxide dismutase, glutathione (GSH) and Malondialdehye (MDA). Estimation of catalase was carried by use of Aebi ${ }^{14}$ preparations, superoxide dismutase by Kakkar et $\mathrm{al}^{15}$, glutathione ${ }^{16}$ by Tietze and malendialdehyde by ohkawa et al. ${ }^{17}$ Levels of chromium are measured by atomic absorption spectophotometery.

\section{Statistical Analysis}

Data was entered in SPSS 21. Variables are expressed as mean \pm SD. Comparison of variables of workers and control subjects was carried out by student't' test. Level of serum chromium was correlated with the antioxidants MDA, CAT, SOD and GSH-Px. The value of $r$ is between +1 and -1 . $P<0.05$ was considered as significant.

\section{RESULTS}

Mean age of workers was 35 years with BMI 23.80 $\mathrm{kg} / \mathrm{m}^{2}$. Their work duration in Fiber glass factory was 6-7 years. Levels of serum chromium and the biological antioxidant was significantly high $(\mathrm{P}<0.001)$ in fiber glass workers as compared to the levels of these parameters of control (Table-I \& II).

A positive weak correlation was observed between serum chromium and antioxidants MDA, SOD and catalase. Whereas, a moderate negative correlation was observed between serum chromium and antioxidant GSH (Figure-4 \& Table-III).

\begin{tabular}{|c|c|c|c|c|c|c|}
\hline Workers (50) & $35.03 \pm 8.83$ & $23.85 \pm 3.90$ & $6.54 \pm 3.42$ & $3.62 \pm 1.05$ & $0.17 \pm 0.13$ & $5.36 \pm 1.99$ \\
\hline Controls (20) & $33.58 \pm 5.40$ & $24.8 \pm 2.80$ & - & $0.93 \pm 0.09 * *$ & $0.06 \pm 0.01 * *$ & $0.15 \pm 0.01 * *$ \\
\hline
\end{tabular}




\begin{tabular}{|l|c|c|c|c|}
\hline \multicolumn{1}{|c|}{ Subjects } & $\begin{array}{c}\text { Duration of work } \\
\text { (Years) }\end{array}$ & $\begin{array}{c}\text { Serum GSH } \\
\text { (mg/d) }\end{array}$ & $\begin{array}{c}\text { Serum Cat } \\
\text { (umol/mol) }\end{array}$ & $\begin{array}{c}\text { Serum Chromium } \\
\text { (mg/L) }\end{array}$ \\
\hline Workers (50) & $6.54 \pm 3.42$ & $2.03 \pm 0.69$ & $0.68 \pm 0.47$ & $5.36 \pm 1.99$ \\
\hline Controls (20) & - & $0.011 \pm 0.01 * *$ & $0.011 \pm 0.01 * *$ & $0.15 \pm 0.01 * *$ \\
\hline \multicolumn{2}{|r|}{ Table-Il. Duration of work and levels of serum chromium and antioxidants in a group of glass fiber workers. } \\
$\mathbf{P}<\mathbf{0 . 0 0 1}=$ Significant difference.
\end{tabular}

\begin{tabular}{|l|c|}
\hline \multicolumn{1}{|c|}{ Correlation } & Glass Fiber Workers \\
\hline Serum MDA with chromium & 0.07 \\
\hline Serum SOD with chromium & 0.05 \\
\hline Serum GSH with chromium * & -0.5 \\
\hline Serum Catalase with chromium & 0.16 \\
\hline
\end{tabular}

Table-III. Coefficient of correlation serum chromium with serum MDA, SOD, GSH and catalase in glass fiber workers.

${ }^{*} p<0.05$

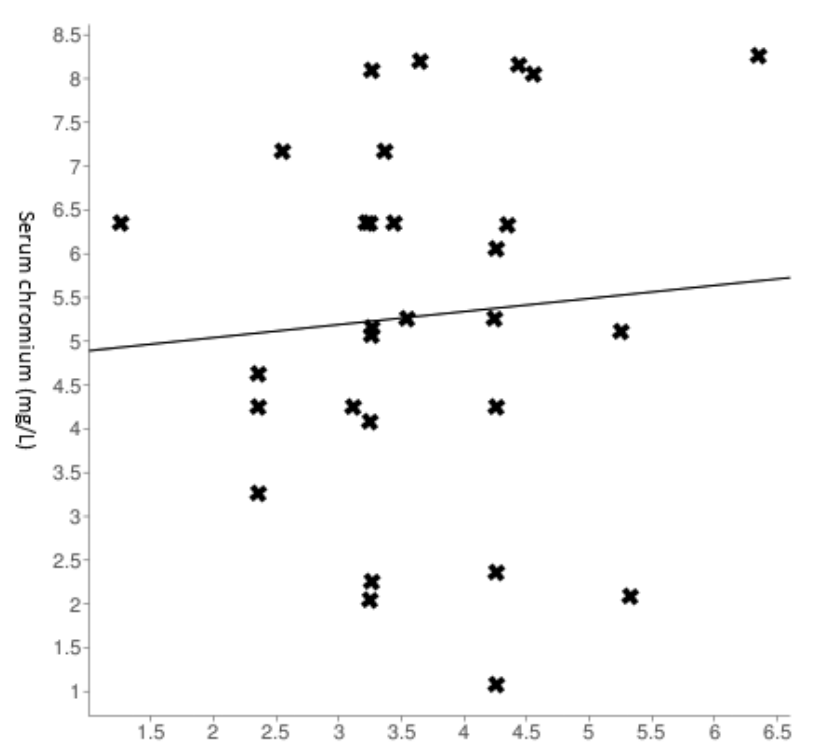

Seurm Malendialdehyde $(\mathrm{nmol} / \mathrm{ml})$

Figure-1. Serum chromium vs MDA $(r=0.07)$.

\section{DISCUSSION}

Exposure of chromium may cause harmful effects on the gastrointestinal, kidney, liver, and immune systems etc. Like other transition metals, including nickel, iron, chromium, zinc and copper, chromium is are toxic because these have the ability to electron exchange and generate ROS in tissues. ${ }^{18}$ We found that most of the workers are lean adults with work duration 6-7 years in Fiber glass factory. We agreed with the study who reported that Long-term exposure of chromium (VI) effects on the system of respiratory

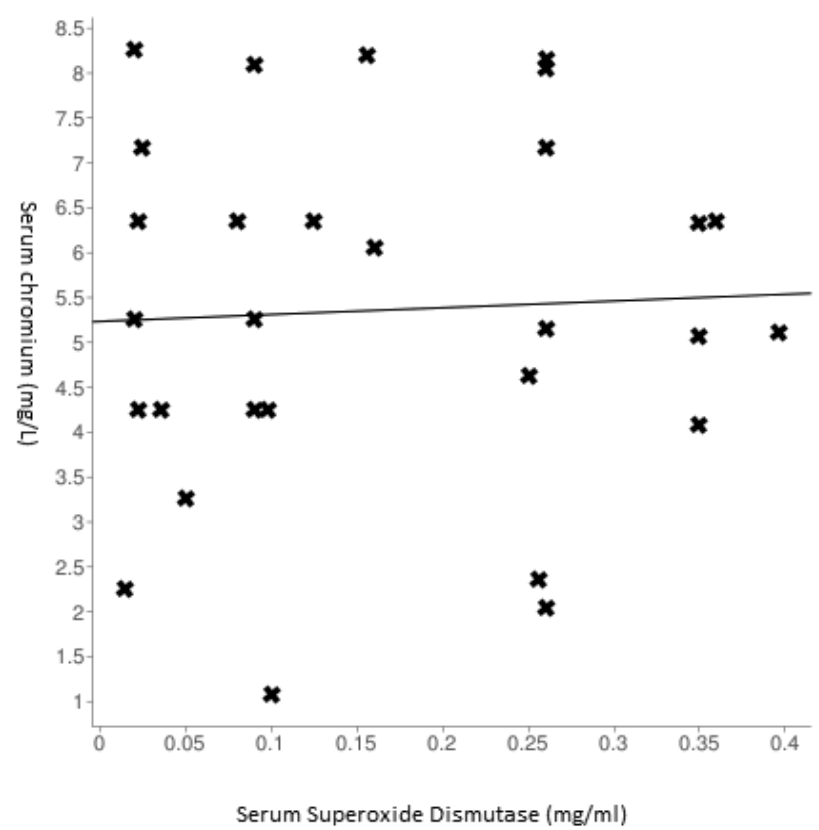

Figure-2. Serum Cr vs SOD ( $r=0.05)$.

tract including ulcerations and perforations of the bronchitis, septum and reduced the function of lungs, results in pneumonia. ${ }^{19}$

We observed that the levels of serum chromium and the biological antioxidant were significantly high $(P<0.001)$ in fiber glass workers as compared to the levels of these parameters of control. It is stated that body have mechanisms by which it prevents the damaging effects of oxyradicals via antioxidants like catalase, superoxide dismutase, glutathione peroxidase, and reductase etc. 


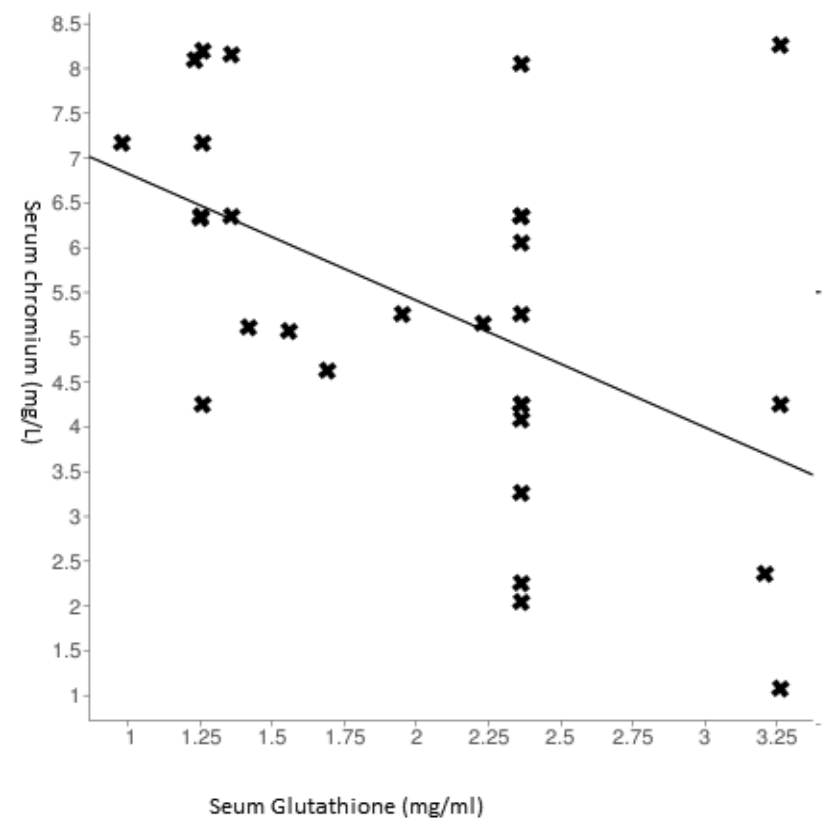

Figure-3. Serum Cr vs GSH ( $r=-0.5)$.

However, long term exposure of transition metals may cause mutation of DNA present in mitochondria. This results in a reduction in energy production. ${ }^{20,21}$

It is proposed that imbalance between generation of free radicals and activity of antioxidants cause oxidative stress. Mild oxidative stress can be tolerated but a higher form of imbalance results in number of diseases. ${ }^{22}$ Metals like chromium, cadmium and arsenic, take part in the development of carcinogens by the generation of DNA lesion due to oxidative stress is and aging by generating free radicals or binding with thiol groups. ${ }^{13}$

A study was carried out on workers of chrome plating factory. An increased concentration of chromium was observed in RBC, lymphocytes and urine of workers with the DNA strand breakage. ${ }^{23}$ It is reported that Chromium and ROS interact with DNA and protein causing the breakage of DNA strand, adducts of chromiumDNA, DNA-protein cross link, and alteration of cell nucleotides. ${ }^{24}$

Although chromium (III) is an essential nutrient, its high exposure via ingestion, inhalation or contact

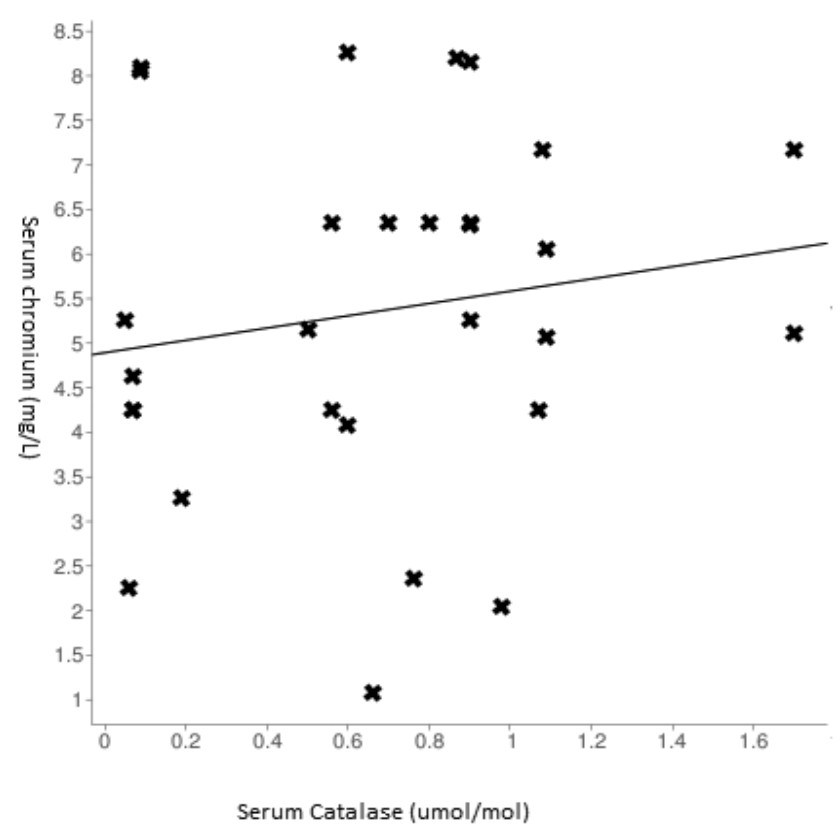

Figure-4. Serum chromium vs catalase $(r=0.16)$.

with skin may give harmful effects. The reduction of chromium (VI) to chromium (III) inside of cells may be an important mechanism for the toxicity of chromium compounds. ${ }^{25}$

The mechanism by which free radicals produced from metals is tightly controlled by antioxidant of cells. Many antioxidants including vitamin C, Vitamin E, glutathione, catalase, superoxide dismutase, flavonoids etc have the ability to chelate the metal ions and decreased their ability to form reactive oxygen species. These antioxidants also have the ability to remove these metal ions by binding with these metal ions. ${ }^{9}$ Foragers of reactive oxygen such as catalase, reduced the process of apoptosis stimulated by chromium. ${ }^{26} \mathrm{GSH}$ protects cells against apoptosis by interrelating with antiapoptotic and proapoptotic signaling trails. ${ }^{27}$ Increased generation of ROS may alter the structure of DNA, results in alteration of lipids and proteins, and synthesis of anti-inflammatory and proinflammatorycytokines. ${ }^{28}$

\section{CONCLUSION}

It is concluded that high level of chromium in workers of fiber glass factory is responsible for increased level of antioxidant in their body, which in long run may develop the diseases especially 
of respiratory tract.

There is a need of awareness of workers to know the hazards related with the chemicals present in their environment as well as they also know the long run effects of exposure of these chemicals. Factors like hand washing, wearing gloves and masks, use of hand sanitizers may protect them by these chemicals.

The limitations of this study include a small number of subjects and the lack to assess the problems associated. Further studies are needed in a larger number of workers to see the effect of metal ions on respiratory distress.

\section{Copyright@ 12 Dec, 2019.}

\section{REFERENCES}

1. Hancu BD, Pop M. Assessment of health effects related to fiber glass exposure in fiber glass workers: Exhaled biomarkers eCO, $\mathrm{FE}_{\mathrm{NO}}$ and their usefulness in the occupational environment testing. Clujul Medical. 2013; 86(2):114-116.

2. Shannon H, Muir A, Haines T, Verma D. Mortality and cancer incidence in Ontario glass fiber workers. Occup Med. 2005; 55:528-534.

3. Guertin, Jacques, James Alan Jacobs, Cynthia P. Avakian, 2005. Chromium (VI) handbook. CRC Press.

4. U.S. EPA, 1998. Integrated Risk Information Service (IRIS) assessment for hexavalent chromium. Available at: http://www.epa.gov/ncea/iris/subst/0144.htm.

5. Agency for Toxic Substances and Disease Registry (ATSDR), 2008. Toxicological profile for chromium (Draft for Public Comment). Atlanta, GA: U.S. Department of Health and Human Services, Public Health Service. Available at: http://www.atsdr.cdc.gov/toxprofiles/tp7.

6. Peralta-Videa R, M. L. Lopez, M. Narayan, G. Saupe, and J. Gardea-Torresdey, "The biochemistry of environmental heavy metal uptake by plants: Implications for the food chain," IntJ of Biochem\& Cell Biol 2009; 41(8-9):1665-1677.

7. Valko M, Jomova K, Rhodes CJ, Kuča K, Musílek K. Redox- and non-redox-metal-induced formation of free radicals and their role in human disease. Arch Toxicol. 2016 Jan; 90(1):1-37.

8. Ding $\mathrm{M}$, Shi X. Molecular mechanisms of $\mathrm{Cr}$ (VI)induced carcinogenesis. Mol Cell Biochem2002; 35(1-2):293-300.
9. Jomova $\mathrm{K}$, Valko M. Advances in metal-induced oxidative stress and human disease.Toxicology. 2011; 283(2-3):65-87.

10. Reyazuddin M, Azmi SA, Islam N, Rizvi A. Oxidative stress and level of antioxidant enzymes in drug-naive schizophrenics. Indian J Psychiatry. 2014; 56(4):344-9.

11. Goulart M, Batoreu M, Rodrigues A, Laires A. \&Rueff J. Lipoperoxidation products and thiol antioxidants in chromium exposed workers. Mutagenesis 2005; 20, 311-315.

12. Halliwell, B. Free radicals and antioxidants-Quo vadis? Trends in Pharmacological Sciences 2011; 32 , $125-130$.

13. Birben E, Sahiner UM, Sackesen C, Erzurum S, Kalayci O. Oxidative stress and antioxidant defense. World Allergy Organ J. 2012; 5(1):9-19.

14. Aebi $\mathrm{H}$, Bergmeyer $\mathrm{HU}$ : Methods in enzymatic analysis, Academic Press Inc, New York.1974; 673686.

15. Kakkar PB, Das P, Viswanathan PN. A modified spectrophotometer assay of superoxide dismutase. Ind J Biochem Bio.1984; 21:130-132.

16. Tietze F. Enzymic method for quantitative determination of nanogram amounts of total and oxidized glutathione: applications to mammalian blood and other tissues. Anal Biochem. 1969; 27:50222.

17. Okhawa $\mathrm{H}$, Ohishi N, Yagi K. Assay for lipid peroxidases in animal tissues by thiobarbituric acid reaction. Anal Biochem. 1979; 95:351-358.

18. Chen C, and Lippmann LM. "Effects of metals within ambient air particulate matter (PM) on human health." Inhalation Toxicology, 2009: 21: 1-31.

19. Caglieri A, Goldoni M, Acampa O, et al. The effect of inhaled chromium on different exhaled breath condensate biomarkers among chrome-plating workers. Environ Health Perspect. 2005; 114(4):542-6.

20. Knight JA. The biochemistry of aging. AdvClin Chem. 2000; 35:1-62.

21. Rahal A, Kumar A, Singh V, et al. Oxidative stress, prooxidants, and antioxidants: The interplay. Biomed Res Int. 2014; $2014: 761264$.

22. Sakac V, Sakac M. [Free oxygen radiacals and kidney diseases--part I]. Med Pregl. 2000 Sep-Oct; 53(910):463-74. 
23. Gambelunghe $A$, Piccinini $R$, Ambrogi $M$, Villarini $M$, Moretti M, Marchetti C, Abbritti G, Muzi G. Primary DNA damage in chrome-plating workers. Toxicology. 2003; 188:187-195.

24. Macfie A, Hagan E, Zhitkovich A. Mechanism of DNAProtein cross-linking by chromium. Chem. Res. Toxicol. 2010, 23, 2, 341-347.

25. Silvio De Flora. Threshold mechanisms and site specificity in chromium (VI) carcinogenesis. Carcinogenesis 2000; 21(4): 533-541.

26. Zhitkovich A. Importance of chromium-DNA adducts in mutagenicity and toxicity of chromium (VI) Chem Res Toxicol. 2005; 18:3-11.
27. Masella R, Di Benedetto R, Vari R, Filesi C, Giovannini C. Novel mechanisms of natural antioxidant compounds in biological systems: Involvement of glutathione and glutathione-related enzymes. J Nutr Biochem. 2005; 16:577-586.

28. Scandalios JG. Genomic responses to oxidative stress. In: Meyers RA, editor. Encyclopedia of molecular cell biology and molecular medicine. 2nd ed. Vol 5. Weinheim, Germany: Wiley-VCH; 2004. pp. 489-512.

\begin{tabular}{|c|c|c|c|}
\hline \multicolumn{4}{|c|}{ AUTHORSHIP AND CONTRIBUTION DECLARATION } \\
\hline Sr. \# & Author(s) Full Name & Contribution to the paper & Author(s) Signature \\
\hline 1 & Uzma Jabbar & $\begin{array}{l}\text { Study design, data collection, } \\
\text { writing the manuscript. }\end{array}$ & \\
\hline 2 & Maira Mahmood & $\begin{array}{l}\text { Formulation of tables reviewed } \\
\text { and approved the manuscript. }\end{array}$ & \\
\hline 3 & Arham Javed & $\begin{array}{l}\text { Statistical analysis, } \\
\text { interpretation of of results. }\end{array}$ & \\
\hline 4 & Naim Ahmad Nizami & $\begin{array}{l}\text { Formulation of tables reviewed } \\
\text { and approved the manuscript. }\end{array}$ & \\
\hline 5 & Mazhar Mushtaq & $\begin{array}{l}\text { Statistical analysis, } \\
\text { interpretation of results, } \\
\text { Reviewed the manuscript. }\end{array}$ & A \\
\hline 6 & Javed Anver Qureshi & $\begin{array}{l}\text { Manuscript writing and revising } \\
\text { it critically for important, } \\
\text { Intellectual content. }\end{array}$ & \\
\hline
\end{tabular}

